\title{
Canine Granular Cell Tumor
}

National Cancer Institute

\section{Source}

National Cancer Institute. Canine Granular Cell Tumor. NCI Thesaurus. Code C158784.

A granular cell tumor occurring in a dog. 